\title{
Characterizing, Explaining and Valuing the Effective Use of an IT Artefact: A Field Study of Performance Management Information Systems in SMEs
}

\author{
Marie Marchand \\ Université du Québec à Trois-Rivières \\ marie.marchand@uqtr.ca
}

\author{
Louis Raymond \\ Université du Québec à Trois-Rivières \\ louis.raymond@uqtr.ca
}

\begin{abstract}
Calls have been made for IS research to shift from the study of the use of IT artefacts to the study of their effective use. In seeking to provide added validity and relevance to the concept of effective use, we apply Burton-Jones and Grange's theoretical framework to study the dimensions, contextual drivers and benefits of effective use. This is done through a field study of performance management information systems (PMIS) as used in 16 small and medium-sized enterprises (SMEs). In characterizing, contextualizing and valuing the effective use of a mission-critical IT artefact such as a PMIS, our results provide further empirical grounding and understanding of this complex yet under researched concept.
\end{abstract}

\section{Introduction}

Calls have been made for IS research to shift from the study of the use of IT artefacts to the study of their "effective" use, resulting from observations that the complexity of many organizational situations with regard to IT artefacts and their use was not accounted for in previous IS usage studies [1]. Given the rather limited implications of these studies for both IS theory and IS practice, the need for a better conceptualization, contextualization and explanation of the use of IT artefacts has been expressed by a number of IS researchers [e.g. 2,3,4].

In a globalized knowledge-based economy, many business enterprises must attain a level of organizational performance such that they can compete on a worldwide basis [5], including small and mediumsized enterprises (SMEs) [6]. Now, one type of IT artefact is deemed critical to support managers in achieving such performance for their organization, namely performance management information systems (PMIS). This artefact is defined as an information system that is based on a holistic view of organisational performance and that supports executive decision-making and strategic management, by producing information that reflects the organisation's "performance logic" [7, p. 674].
The need for a better conceptualization, contextualization and explanation of the use of PMIS and a better comprehension of their role in the organization has also been expressed by researchers in the performance management field [e.g. 8,9], the goal being to produce research results that are not only valid theoretically but also useful practically for the design, use and management of these information systems $[10,11]$.

Given the preceding considerations, the aim of this study is to generate empirically-valid and useful findings with regard to the characterization and explanation of PMIS' effective use in the context of SMEs. Thus the following research questions: What constitutes the effective use of PMIS? What are the user, artefactual and task-related drivers of such use? And what are its benefits for SMEs?

\section{Theoretical background}

The ambiguity that surrounds the notion of system usage in the IS research domain is a source of problems with regard to the conceptualization and operationalization of this notion [12]. An inappropriate or inadequate conceptualization will not provide the contextualization required to fully understand the usage phenomenon under study, will produce mixed results that are difficult to interpret and can lead to erroneous conclusions, particularly when dealing with complex information systems [2,13]. Moreover, an inappropriate or inadequate measurement of IS usage founded upon superficial indicators (e.g. duration and frequency of use) that neglect the task-related aspects, or upon binary variables (0: non-use, 1: use) or upon proxies (adoption vs use) will not be able to grasp the true nature of the use of a complex IT artefact such as a PMIS $[1,4,14,15,16]$. For example, the mere adoption of a technology does not mean much as to the impacts on productivity that its actual use will have [13].

This measurement problem may be seen as an indication of a conceptualization of IT use that lacks contextualization or assumes use contexts to be interchangeable. By limiting the explanatory power of contextual elements, our comprehension of the phenomenon is then limited. With regard to the IT 
artefactual context in particular, one could even say such reductionist approaches assume that all IT artefacts are alike or that their attributes have no importance in understanding their use. A judicious choice of usage variables and measures is thus necessary, if the researcher is to relate an information system's attributes to the performance of the task $[4,17]$.

Complex information systems rest upon multiple elements and inter-related IT processes capable of integrating in a logical ensemble the firm's operational and managerial processes across its various business functions $[2,4]$. These systems are called upon to evolve with needs of users whose type and level of competency differ [13]. For this reason, the study of the use of complex IS should be founded upon approaches that allow one to encompass the full range of the phenomenon in its specific context [4,14], given that the habitual constructs and measures of IS usage do not allow one to understand the cases where there is a lack of appropriation of the system by users, where there is unexpected use of the system, where the system is under-used, and where its expected benefits are not realized $[2,14]$.

The need for a richer conceptualization and measurement of IS usage is now well-recognized by researchers, in particular when this use is meant to support users in "cognitively engaging tasks" [14]. By taking into account critical contextual elements such as the nature of use, its extent, its quality and the user's expectations, one should attain a better understanding of a complex information system's impacts and of the value or benefits realized from its use [e.g. 18,19]. This is borne out in a number of empirical studies where, in order to face a diversity of complex systems in a large number of organizations, IS usage is not primarily approached from its technological aspects but rather from its teleological aspects such as its support of the firm's management, strategy and decision making [e.g. $16,20]$.

Reflecting the different approaches that have been taken to solve these problems of conceptualization and operationalization, many definitions of IS/IT usage/use or ancillary concepts can be retraced in the literature. This includes, for instance, the following concepts: cognitive absorption ("a state of deep involvement with software" [21, p. 665]); user competence ("the user's potential to apply technology to its fullest extent so as to maximize performance of specific job tasks" [22, p. 38]); quality of use ("one's ability to correctly exploit the appropriate capabilities of software in the most relevant circumstances" [2, p. 3]); IS continuance ("behavior patterns reflecting continued use of a particular IS” [23, p. 472]).
Notwithstanding the previous research efforts, the use of complex IS remains a phenomenon that is still lacking in characterization, explanation and contextualization. Now, in view of the definition of PMIS given above, these systems are considered to be complex. And because of their strategic or "missioncritical" nature, PMIS are highly contextualized [7,24]. While there have not been many empirical studies on the subject of their use, be it in SMEs or in large enterprises, it appears that the use of such systems is continuous in nature, focused on the system's informational content, and influenced by the management style and culture of the organization [25].

\section{Research model}

Being part of a network of influences, PMIS usage can be theorised as context-bound independent or dependent construct integrated in a nomological network [26]. In seeking to provide added validity and relevance to the concept of use, we apply Burton-Jones and Grange's [3] theoretical framework to study the dimensions, contextual drivers and benefits of the effective use of PMIS in SMEs, as synthesized in the research model presented in Figure 1.

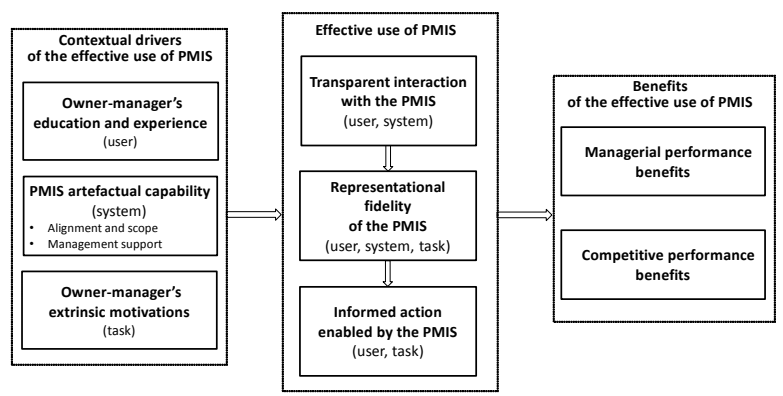

Figure 1. Research model

(adapted from Burton-Jones and Grange [3])

One should note at this juncture that the theoretical foundations of Burton-Jones and Grange's [3] effective use framework rest primarily upon representation theory [27,28], wherein representations of reality (to the extent that they are "faithful") enable action and thus constitute the essence of any information system. This framework also relies upon affordance theory [29] through its interest not only in the physical and sensory attributes of the IT artefact's user-interface (physical and sensory affordance) but also in those attributes that support the user's cognitive ability (cognitive affordance) and capacity to take action in the pursuance of a goal (functional affordance). Within this theoretical context, the three aspects to be prioritized are the user, the information system and the task (defined as "goal-directed activity") [3,14]. 
We thus followed Burton-Jones and Grange's [3] approach because we deemed it to be most appropriate to our research aim of characterizing and explaining the effective use of PMIS in a SME context, given its encompassing multiple dimensions of effective use and its organizing of these dimensions into a coherent ensemble. In reaching beyond the purely artefactual dimension of use, this framework incorporates other rarely considered dimensions that are more specifically linked to what happens after the user's interaction with the system. Finally, it constitutes a measurement basis that provides us with the capacity to contextualize a complex IT artefact such as a PMIS in a particularly rich manner.

\subsection{Effective use of the PMIS artefact}

Effective use is defined by Burton-Jones and Grange $[3$, p. 633) "as using a system in a way that helps attain the goals for using the system". This notion is conceptualized as three sequentially related components or dimensions: 1) the physical access to the information system by the user (transparent interaction), 2) the representation of an individual, organizational or environmental reality that this system provides to the user (representational fidelity), and 3) the action that it allows the user to envision (informed action) [3, p. 642]. Transparent interaction is thus viewed as a necessary condition of representational fidelity, which in turn is viewed as a necessary condition of informed action.

As advocated by Burton-Jones and Straub [14], our research model explicitly relates each dimension of effective use to the aspects involved in the usage of a complex information system: the user, the system itself, and the task meant to be supported. Our ensuing contextualization of the effective use of PMIS was based on the findings of previous IS $[3,4,14]$ and performance management [30,31,32] studies.

Transparent interaction with the PMIS (user/system-related). Defined as the "extent to which a user is accessing the system's representations unimpeded by its surface and physical structures" [3, p. 642], this component of the research model reflects the interaction of the SME owner-manager with the PMIS artefact.

Representational fidelity of the PMIS (user/system/task-related). Defined as the "extent to which a user is obtaining representations from the system that faithfully reflect the domain being represented" [3, p. 642), this dimension of effective use reflects the perceived quality of the information output by the PMIS in relation to the owner-manager's task.

Informed action enabled by the PMIS (user/taskrelated). Defined as the "extent to which a user acts upon the faithful representations he or she obtains from the system to improve his or her state" [3, p. 642], this dimension reflects the enablement by the PMIS of the actions required of owner-managers in the course of their management of the SME's performance.

\subsection{Contextual drivers of effective use of PMIS}

In line with Burton-Jones and Grange's [3] theoretical framework, all three dimensions of the effective use of PMIS are expected to be influenced by contextual elements related to the user, to the PMIS artefact he or she uses, and to his or her task as ownermanager of a SME.

User's education and experience (user-related). SME owner-managers' socio-demographic attributes such as their age, gender, education and experience have long been known to influence their managerial behavior [33]. With respect to the use of a PMIS, we expect that owner-managers' with the greater general knowledge and greater capacity for analysis, synthesis and abstraction gained from a higher education as well as the greater context-specific knowledge gained from a longer experience in the task and in the work domain will make more effective use of such a complex IS [34].

PMIS artefactual capability (system-related). System usage behaviors are obviously bound by IT artefactual capabilities, i.e. those functional attributes of the IS that determine what can and cannot be done by the user with the system [27,29]. In the case of a PMIS artefact, we expect its effective use by a SME owner-manager to be primarily driven by two artefactual capabilities [7]. The first capability relates to the range of indicators present in the system that allow owner-managers to assess the different aspects of their firm's performance in a holistic manner (level of alignment and scope of the PMIS artefact). The second capability relates to the system's facilitation of the use of the performance information output for managerial decision making and action purposes (management support functionalities of the PMIS artefact).

User's extrinsic motivations (task-related). In an organizational IS context, the extrinsic motivations of a user are based upon his or her perception of the system's usefulness, this perception resting upon the task-related usage goals defined ex ante by the user [35]. Behavioral theories such as the theory of reasoned action and the theory of planned behavior have been oft-employed in IS research to successfully predict usage behaviors from such motivations [23]. In our case, the SME owner-managers' extrinsic motivations that are meant to predict their effective use of PMIS are based upon the expected usefulness of the system with respect to three primary usage goals, as 
identified previously in the performance management literature $[36,37,38]$. The first goal assigned by ownermanagers to the use of a PMIS is to support their firm's strategic planning process, the second is to support its continuous improvement process, and the third is to support its operations management process. We thus postulate that the greater the importance accorded to these goals by owner-managers, the more effective their use of PMIS.

\subsection{Benefits of effective use of PMIS}

The primary benefits of the effective use of PMIS are postulated here to be the organizational improvements obtained by a SME in terms of its managerial (internal) performance and competitive (external) performance. The assumed relationship between PMIS use and performance is based on the findings of previous performance management studies $[10,11,39]$ and on IS success/benefits/effectiveness measurement models previously developed and validated by IS researchers $[40,41,42]$. Our research model diverges in this regard from Burton-Jones and Grange's [3] proposal in that these authors conceptualize the performance benefits of effective use at the individual level (effectiveness and efficiency of the user). Moreover, our research model initially assumes that all three dimensions of the effective use of PMIS will have a positive impact on the SMEs' attainment of performance benefits.

\section{Research method}

In characterizing the use of the PMIS artefact, we adopted a perspective that respects the ontological value of this artefact. A positivist realist posture was thus taken to achieve this aim [43], while simultaneously accounting for the researchers' presence and involvement in situ [44].

\subsection{Research design and sampling}

Contextualizing, in space and time, the use of an IT artefact entails a trade-off between explanatory power and theoretical parsimony. The choice of a research strategy that combines scope and depth takes into consideration the complexity of the environmental and organizational contexts while controlling for relevant variables $[45,46]$. To this effect, using a multiple case study or field study strategy in the sense of Boudreau, Gefen and Straub [47] is an appropriate research strategy as it reduces dependence from the contexts and simultaneously favours the transferability and generalizability of the study's results [48].

The case study's theoretical sampling criteria were set to identify the PMIS artefact among the firm's organizational information system (OIS) [31]. As presented in Table 1, sixteen SMEs located in different regions of the province of Quebec, Canada, and showing a variety of contexts for the firms' size, age and industrial sector were thus selected. To ensure the selection of firms with PMIS meeting criteria as well as to provide richness of experiences, phone calls and e-mails were exchanged with the firms' ownermanager prior to the case interviews.

Table 1. Characterization of the sample

\begin{tabular}{|c|c|c|c|c|c|c|c|c|}
\hline Firm ID & $\mathbf{A}$ & B & C & D & $E$ & $\mathbf{F}$ & G & $\mathrm{H}$ \\
\hline $\begin{array}{l}\text { No. of } \\
\text { empl. }\end{array}$ & 16 & 43 & 70 & 39 & 135 & 250 & 55 & 65 \\
\hline $\begin{array}{l}\text { Age of } \\
\text { firm }\end{array}$ & 30 & 17 & 28 & 30 & 32 & 43 & 35 & 13 \\
\hline Sector & $\begin{array}{l}\text { Electronics } \\
\text { telecom. }\end{array}$ & Construction & 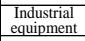 & Chemical & \begin{tabular}{|l|}
$\begin{array}{l}\text { Industrial } \\
\text { equipment }\end{array}$ \\
\end{tabular} & Chemical & Construction & Construction \\
\hline PMIS & \begin{tabular}{|l} 
different \\
DBs: \\
accounting/ \\
cost, orders, \\
production \\
quality
\end{tabular} & $\begin{array}{l}\text { organisation } \\
\text { DB: } \\
\text { Dccounting/ } \\
\text { cost, sales, } \\
\text { production }\end{array}$ & $\begin{array}{l}\text { organisation } \\
\text { DB: } \\
\text { accounting/ } \\
\text { cost, sales, } \\
\text { pRMM } \\
\text { production }\end{array}$ & $\begin{array}{l}\text { organisation } \\
\text { DB: } \\
\text { Dccounting/ } \\
\text { cost, sales, } \\
\text { production }\end{array}$ & \begin{tabular}{|c|} 
different \\
DBs: \\
accunting/ \\
cost, \\
CRM, \\
HRM, \\
production, \\
engineering
\end{tabular} & $\begin{array}{l}\text { organisation } \\
\text { DB /ERP: } \\
\text { accounting/ } \\
\text { cost, sales, } \\
\text { HRM, } \\
\text { production }\end{array}$ & \begin{tabular}{|c|} 
different \\
DBs: \\
accounting/ \\
cost, orders
\end{tabular} & \begin{tabular}{|c} 
different \\
DBS: \\
accounting/ \\
costst clients, \\
production
\end{tabular} \\
\hline Firm ID & $\mathbf{K}$ & $\mathbf{L}$ & M & $\mathbf{N}$ & 0 & $\mathbf{P}$ & $\mathbf{Q}$ & $\mathbf{R}$ \\
\hline $\begin{array}{l}\text { No. of } \\
\text { empl. }\end{array}$ & 75 & 130 & 96 & 524 & 25 & 40 & 23 & 15 \\
\hline $\begin{array}{l}\text { Age of } \\
\text { firm }\end{array}$ & 34 & 30 & 25 & 65 & 31 & 18 & 17 & 47 \\
\hline Sector & $\begin{array}{l}\text { Industrial } \\
\text { equipment }\end{array}$ & \begin{tabular}{|l|}
$\begin{array}{l}\text { Industrialal } \\
\text { equipment }\end{array}$ \\
\end{tabular} & $\begin{array}{l}\text { Electronics } \\
\text { /telecom. }\end{array}$ & Construction & Construction & Chemical & $\begin{array}{l}\text { Industrial } \\
\text { equipment }\end{array}$ & Construction \\
\hline PMIS & $\begin{array}{l}\text { organisation } \\
\text { DB/ERP: } \\
\text { accounting/ } \\
\text { cost, orders, } \\
\text { HRM, } \\
\text { production }\end{array}$ & $\begin{array}{c}\text { different } \\
\text { DBs: } \\
\text { accounting/ } \\
\text { cost, sales, } \\
\text { HRM, } \\
\text { production }\end{array}$ & $\begin{array}{l}\text { organisation } \\
\text { DB/ER: } \\
\text { accounting/ } \\
\text { cost, sales, } \\
\text { HRM, } \\
\text { production }\end{array}$ & $\begin{array}{l}\text { organisation } \\
\text { DB: } \\
\text { accounting/ } \\
\text { cost, sales, } \\
\text { production }\end{array}$ & $\begin{array}{l}\text { organisation } \\
\text { DB: } \\
\text { accounng } / \\
\text { cost sales } \\
\text { production }\end{array}$ & $\begin{array}{l}\text { organisation } \\
\text { DB: } \\
\text { accounting/ } \\
\text { costs sales, } \\
\text { HRM, } \\
\text { production }\end{array}$ & $\begin{array}{l}\text { organisation } \\
\text { DB: } \\
\text { accounting/ } \\
\text { cost, sales, } \\
\text { HRM }\end{array}$ & \begin{tabular}{|l} 
different \\
DBs: \\
accounting/ \\
cost, orders
\end{tabular} \\
\hline
\end{tabular}

\subsection{Data collection}

Both flexible and structured data collection methods were employed, thus allowing for a number of different data types as well as their triangulation and corroboration [46]. The user being the individual possessing the most knowledge of the PMIS artefact, employing a methodological approach that encourages the expression of his or her usage experience becomes necessary. The user is thus asked to present the PMIS artefact he or she uses, and in his or her usage context. It is important to recall at this juncture that when the user's perspective is not taken into account, one cannot accurately describe and truly understand the role that usage plays in the configuration of the IT artefact [49].

Combining qualitative and quantitative data analyses, we conducted extensive interviews in situ with the SMEs' owner-manager. This individual's influence in formulating his or her firm's strategy and managing its performance is the key to inform these aspects [50] and consequently to describe the IT artefact dedicated to managing organizational performance. The interview was initiated with two open questions: What is your definition of organizational performance as it applies to your firm? 
In what manner do you measure and manage this performance, and what tools do you employ to do so? The interview then continued with the commented administration of a questionnaire on the PMIS artefact, its use and its performance benefits, in addition to contextual variables.

The interview was audio-recorded and notes were taken throughout its course. These notes as well as reflective comments were transcribed in the following 24 hours [45]. Available print documents relating to the PMIS artefact were also collected and examined. Data collection activities were conducted over a 15month period and carried out in parallel with the data analysis, to allow for necessary adjustments [45].

\subsection{Measurement and data analysis}

The three components of the effective use of PMIS were ascertained by adapting Burton-Jones and Grange's [3] as well as other measures of IS use taken from the extant IS literature [4,14] and performance management literature $[25,30,31,32]$, through ten linear, numeric scales (transparent interaction with the PMIS, representational fidelity of the PMIS) and five Likert scales (informed action enabled by the PMIS) as presented in Appendix A. The two dimensions of the PMIS' artefactual capability (alignment and scope, management support) were measured respectively through twelve and nine Likert scales based on the range of functionalities found in such systems [7].

In line with previous measurement models of IS success, benefits or effectiveness $[38,39,40]$, the managerial performance and competitive performance benefits of the effective use of PMIS were assessed respectively through five and eight Likert scales culled and adapted from the performance management literature [10,11,39]. Extrinsic motivations were measured by assessing the importance accorded by the owner-manager to three primary goals of PMIS use culled from the performance management literature [e.g. 36,37]. The owner-manager's level of schooling (high-school, college or university), years as head of the firm (task experience) and years in the firm's sector of activity (industry experience) were used as measures of the user's education and experience.

The research questions were addressed with exact correlational, variance and regression analyses [51], cluster analysis and Runkel's [52] relative frequencies analysis. This last type of analysis aims to find associations between two variables by using the calculus of probabilities, that is, by testing for the interdependence of events through a comparison of the actual relative frequency of joint events to the frequency to be expected if the events were independent of one another. Note that all four types of analysis use statistical strategies that are particularly appropriate for small sample research [53].

\section{Results}

\subsection{Characterizing the effective use of PMIS}

In applying and testing Burton-Jones and Grange's [3] framework to characterize the effective use of a PMIS artefact, one must first examine the relationship between the three components of effective use, namely transparent interaction with the artefact (TI), representational fidelity of the artefact (RF) and informed action enabled by the artefact (IA). Now the correlational analysis presented in Table 2 provides evidence of the sequential nature of this relationship, as postulated by these authors $(\mathrm{TI} \rightarrow \mathrm{RF} \rightarrow \mathrm{IA})$, as $\mathrm{TI}$ is shown to be significantly correlated to RF but not to IA, whereas RF is significantly correlated to IA. Moreover, a relative frequencies analysis allows us to determine that the ease of use and completeness of the information output by the PMIS artefact are the two aspects of its representational fidelity that most benefit from a more transparent interaction with this artefact. In similar fashion, "fostering the emergence of new ideas" is the key aspect of the informed action enabled by the PMIS artefact that benefits from a greater representational fidelity of this artefact. These initial results thus offer a both novel and confirmatory operationalization of Burton-Jones and Grange's [3] theoretical framework of the dimensions of the effective use of an IT artefact.

\section{Table 2. Interrelationship of the dimensions of effective use}

\begin{tabular}{|c|c|c|c|}
\hline \multirow{3}{*}{$\begin{array}{l}\text { Effective use of PMIS } \\
\text { Dimension }\end{array}$} & \multicolumn{3}{|c|}{ Effective use of PMIS } \\
\hline & TI & $\mathbf{R F}$ & IA \\
\hline & $\mathrm{R} \quad(\mathrm{p})$ & $\mathrm{R} \quad(\mathrm{p})$ & $\mathrm{R} \quad(\mathrm{p})$ \\
\hline $\begin{array}{l}\text { Transparent interaction } \\
\text { with the PMIS (TI) }\end{array}$ & - & & \\
\hline $\begin{array}{l}\text { Representational fidelity } \\
\text { of the PMIS ( } \mathbf{R F} \text { ) }\end{array}$ & $0.46(.076)$ & - & \\
\hline $\begin{array}{l}\text { Informed action enabled } \\
\text { by the PMIS (IA) }\end{array}$ & $0.35(.188)$ & $0.56(.023)$ & - \\
\hline
\end{tabular}

Nota. Dark | light grey-shaded cells indicate a significant relationship (exact statistics, $\mathrm{n}=16, \mathrm{p}<0.05 \mid 0.1$ ).

\subsection{Contextualizing the effective use of PMIS}

In contextualizing the effective use of a PMIS artefact, and given our research questions, we must first identify primary determinants of effective use at the user and artefactual levels, as well as the components of this use (TI, RF and/or IA) that are thus 
determined. This first implies an examination of the effect of the user's education and experience upon his or her effective use of a PMIS, as proposed in the research model (Figure 1). Now the correlational analysis presented in Table 3 indicates that it is the user's level of education rather than experience that is associated with a more effective use of PMIS in terms of RF and IA, but not in terms of TI. Here, the capacity to analyze, to synthesize and to transform information into actionable knowledge that is provided to the SME owner-manager by a university education may not be as readily developed solely from experience.

Table 3. Relationship of the user's education and experience with effective use

\begin{tabular}{|l|c|c|c|}
\hline \multirow{2}{*}{$\begin{array}{l}\text { User's education } \\
\text { and experience }\end{array}$} & \multicolumn{4}{|c|}{ Effective use of PMIS } \\
\cline { 2 - 5 } & $\mathrm{R}$ & TI & \multicolumn{2}{|c|}{ RF } & \multicolumn{2}{|c|}{ IA } \\
\hline University education & $0.14(.609)$ & $0.43(.094)$ & $0.49(.056)$ \\
\hline Task experience & $0.04(.888)$ & $0.37(.158)$ & $0.34(.201)$ \\
\hline Industry experience & $0.02(.946)$ & $0.41(.117)$ & $0.23(.383)$ \\
\hline
\end{tabular}

Nota. Light grey-shaded cells indicate a significant relationship (exact statistics, $\mathrm{n}=16, \mathrm{p}<0.1$ ).

Cluster analysis was used to classify and characterize the sixteen PMIS observed by an artefactual capability profile. A four-cluster solution was most parsimonious, identifying groups of PMIS artefacts that could be clearly distinguished from one another based on the meaningful pattern of relationships among its artefactual attributes (clustering variables) [54].

As presented in Table 4, a first cluster regrouping four PMIS artefacts (B,D,G,R) was labelled operational PMIS. These artefacts are characterized by a weak capability both in terms of alignment and scope and in terms of management support. A second cluster comprised of two PMIS artefacts (A,H) was named managerial PMIS, as these two artefacts are characterized by a high degree of management support. Their information processing capacity assures an average or standard coverage of performance, and essentially aims to provide information that is easy to use by operational-level managers. The third cluster, regrouping six PMIS artefacts $(\mathrm{E}, \mathrm{K}, \mathrm{L}, \mathrm{N}, \mathrm{O}, \mathrm{Q})$, was labelled functional PMIS. As these artefacts show a strong degree of alignment and have a wide scope, they allow for a more holistic measurement of performance, i.e. both horizontally (business processes and projects) and vertically (business functions), and both at the operational and strategic management levels. The last cluster comprised of four PMIS artefacts $(\mathrm{C}, \mathrm{F}, \mathrm{M}, \mathrm{P})$, was named organizational PMIS. These artefacts are the ones that show strong capabilities both in terms of alignment and scope and in terms of management support.

\section{Table 4. Classification of the PMIS on the} basis of their artefactual capability

\begin{tabular}{|l|c|c|c|c|}
\hline $\begin{array}{l}\text { Artefactual profile } \\
\text { PMIS artefactual } \\
\text { capability (SMEs) }\end{array}$ & Org. & Funct. & Manag. & Oper. \\
\hline Alignm. and scope & strong & strong & medium & weak \\
\hline Mgmt. support & strong & medium & strong & weak \\
\hline
\end{tabular}

The relationship between the four PMIS artefactual capability profiles and the effective use of PMIS is assessed by the analysis of variance results presented in Table 5. Here, one first observes that the managerial and organizational PMIS artefact profiles are significantly associated to the effective use of the PMIS because they both have a strong management support capability that better enables users to take informed action. A somewhat more surprising result is that the operational PMIS profile is also significantly associated to effective use, here in terms of representational fidelity. A possible explanation would be that the operational orientation of these PMIS artefacts makes for simpler software design (limited number of performance indicators and managerial functionalities) and thus makes it easier to output performance information that is up to date, relevant, complete, easy to use and easy to interpret by their targeted users.

Table 5. Relationship of the PMIS artefactual capability with effective use

\begin{tabular}{|c|c|c|c|}
\hline \multirow{3}{*}{$\begin{array}{l}\text { PMIS artefactual } \\
\text { profile }\end{array}$} & \multicolumn{3}{|c|}{ Effective use of PMIS } \\
\hline & TI & RF & IA \\
\hline & $\mathrm{F} \quad(\mathrm{p})$ & $\mathrm{F} \quad(\mathrm{p})$ & \\
\hline Organizational PMIS & $0.34(.572)$ & $0.17(.683)$ & $3.94(.067)$ \\
\hline Functional PMIS & $0.00(.990)$ & $0.18(.678)$ & $0.14(.716)$ \\
\hline Managerial PMIS & $1.81(.200)$ & $2.50(.137)$ & $11.1(.005)$ \\
\hline Operational PMIS & $0.15(.707)$ & $5.58(.033)$ & $0.32(.578)$ \\
\hline
\end{tabular}

Nota. Dark | light grey-shaded cells indicate a significant relationship (exact statistics, $\mathrm{n}=16, \mathrm{p}<0.05 \mid 0.1$ )

The results of the variance analysis linking users' extrinsic motivations to their effective use of PMIS are presented in Table 6. Here one finds that when the SME owner-managers' goal in using a PMIS artefact is to support either or both of their firm's strategic planning process and continuous improvement process, effective use ensues in terms of the PMIS artefact's greater representational fidelity. Whereas when the goal is to support operations management, effective use ensues in terms of the better-informed action enabled by this artefact. This last result again comforts 
the shift of our research attention from the use of an IT artefact to its effective use [Burton-Jones and Grange $3]$, in that it provides a further explanation as to the conditions under which and the manner by which ITbusiness value is achieved by an organization that has invested in IT.

\section{Table 6. Relationship of the user's extrinsic motivations with effective use}

\begin{tabular}{|l|c|c|c|}
\hline \multirow{2}{*}{$\begin{array}{l}\text { User's extrinsic } \\
\text { motivations } \\
\text { (goals of PMIS use) }\end{array}$} & \multicolumn{4}{|c|}{ Effective use of PMIS } \\
\cline { 2 - 5 } & $\mathrm{F}$ & TI & \multicolumn{2}{|c|}{ RF } & $\mathrm{F}$ & \multicolumn{2}{|c|}{ IA } \\
\hline $\begin{array}{l}\text { Support strategic } \\
\text { planning process }\end{array}$ & $0.80(.385)$ & $\mathrm{F}$ & $10.90(.005)$ \\
\hline $\begin{array}{l}\text { Support continuous } \\
\text { improvement process }\end{array}$ & $2.31(.151)$ & $3.39(.087)$ & $0.35(.563)$ \\
\hline $\begin{array}{l}\text { Support operations } \\
\text { management process }\end{array}$ & $0.22(.649)$ & $0.27(.613)$ & $6.79(.021)$ \\
\hline
\end{tabular}

Nota. Dark | light grey-shaded cells indicate a significant relationship (exact statistics, $\mathrm{n}=16, \mathrm{p}<0.05 \mid 0.1$ )

\subsection{Valuing the effective use of PMIS}

As presented in Table 7 , the results of two regression analyses relate the three dimensions of the effective use of PMIS (TI, RF, and IA) to both the managerial performance and competitive performance benefits of this use, as perceived by the sixteen SME owner-managers.

Table 7. Performance benefits of the effective use of PMIS

\begin{tabular}{|c|c|c|}
\hline \multirow{3}{*}{$\begin{array}{l}\text { Effective use of PMIS } \\
\text { (independent variables) }\end{array}$} & \multicolumn{2}{|c|}{$\begin{array}{c}\text { Benefits of the effective use } \\
\text { of PMIS } \\
\text { (dependent variable) }\end{array}$} \\
\hline & $\begin{array}{l}\text { Managerial } \\
\text { performance }\end{array}$ & $\begin{array}{l}\text { Competitive } \\
\text { performance }\end{array}$ \\
\hline & & $\mathrm{T} \quad(\mathrm{p})$ \\
\hline $\begin{array}{l}\text { Transparent interaction } \\
\text { with the PMIS (TI) }\end{array}$ & $0.00 \quad(.381)$ & $1.58 \quad(.139)$ \\
\hline $\begin{array}{l}\text { Representational fidelity } \\
\text { of the PMIS (RF) }\end{array}$ & $1.81 \quad(.774)$ & $1.13 \quad(.282)$ \\
\hline $\begin{array}{l}\text { Informed action } \\
\text { enabled by the PMIS (IA) }\end{array}$ & $0.15 \quad(.037)$ & $(.020)$ \\
\hline $\begin{array}{c}\mathrm{F}(\mathrm{p}) \\
\text { adjusted } \mathrm{R}^{2}\end{array}$ & $\begin{array}{c}4.23 \quad(.030) \\
0.39\end{array}$ & $\begin{array}{c}9.31(.002) \\
0.62\end{array}$ \\
\hline
\end{tabular}

Nota. Dark grey-shaded cells indicate a significant relationship (exact statistics, $\mathrm{n}=16, \mathrm{p}<0.05$ ).

The salient finding here is that the realization of benefits from the use of a PMIS artefact is solely dependent upon the informed action that is enabled by this artefact. While neither transparent interaction with the PMIS nor its representational fidelity were found to have a direct effect upon performance, these two dimensions of effective use would nevertheless have an indirect effect, as one may recall that they are sequentially prerequisite to informed action. Furthermore, these last results confirm Leonardi's [55] view in that it is through informed action that the informational capabilities of an IT artefact are leveraged and thus generate value for the SMEs that have invested in this IT artefact.

\section{Discussion and implications}

To summarize our findings, and given our research questions and model, the nomological network that emerged from this initial validation is presented in Figure 2. A first point to be made is that the three dimensions of effective use are indeed hierarchically related as postulated in Burton-Jones and Grange's [3, p. 643-644] framework, that is, TI enables RF which in turn enables IA. In accordance with these authors, it thus becomes important to assess each dimension as a function of use rather than as a function of an IT artefact or a user, and to assess the context of use if one aims to theorize and operationalize the concept of effective use.

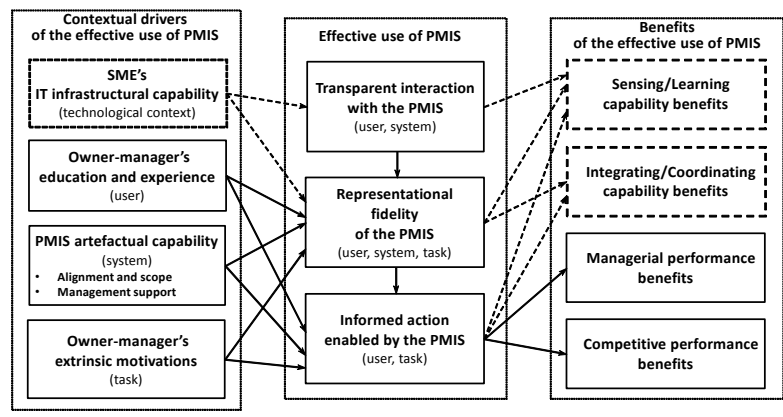

Figure 2: Nomological network emerging from our initial validation of the research model

The second point is that informed action was the lone dimension of effective use to have an effect on performance. This finding diverges from Burton-Jones and Grange's [3] proposal in that all three dimensions of effective use should have impacted the attainment of performance benefits by SMEs that have invested in a PMIS. Now, this divergence may be due to these authors conceptualization of performance at the individual level (effectiveness and efficiency of the user), whereas in this study, performance was conceptualized at the organizational level (managerial and competitive performance of the SME), albeit as assessed by the owner-manager who is the primary user of the PMIS and is well-placed to make such an assessment [34]. However, it stands to reason that other than performance, the development of the firm's 
dynamic capabilities and chief among them its sensing, learning, integrating and coordinating capabilities are most susceptible to benefit from the effective use of a PMIS artefact [32,56]. We have thus included in the nomological network the development of these two dynamic capabilities as an added value of the effective use of PMIS.

A third point to be made is that transparent interaction was the lone dimension of effective use not to be influenced by any of the hypothesized userrelated, system-related or task-related antecedents. Now, it stands to reason that the firm's IT resources and capabilities, chief among them its IT infrastructure, are the contextual elements most susceptible to influence its effective use of IT artefacts such as PMIS [57]. We have thus included in the nomological network, for future research purposes, the SME's IT infrastructural capability as a potentially enabling factor of the owner-manager's - and other managers' transparent interaction with the PMIS artefact or with any other of the firm's "mission-critical" IT artefacts for that matter (e.g. ERP).

Given its results, the contribution of this study to IS research in general and to PMIS research in particular are significant. First of all, our application and operationalization of Burton-Jones and Grange's [3, p. 632] theoretical framework was found to be initially valid and fruitful in further exploring the concept of effective use, a concept that is "quite complex" and "extremely under researched". Secondly, as many IS researchers are still preoccupied with the study of complex organizational information systems in decision-support roles and the realization of IT business value from such use, our study contributes to the integration of these research efforts through a conceptualization and operationalization of IT use that is adapted to this type of IT artefact [26]. Third, our conceptualization and operationalization of the IT artefactual capabilities included in the research model answer the call for IS researchers to account for the central position of the IT artefact (or IT materiality) in further attempts to understand why, how and to what effect individuals use IT [28,49].

Finally, as the use of PMIS and the performance benefits of such use are not yet well understood [37], and especially in the context of SMEs [36], the results of this study may provide the conceptual and empirical foundations to improve PMIS practice in this context. For instance, with regard to the design of a PMIS artefact, one would concentrate on those artefactual attributes that most enable informed action on the part of owner-managers, as it is these actions that have been shown to have the greater consequences for the realization of IT business value in SMEs.

\section{Conclusion}

While this field study has some obvious limitations related to the nature and size of the sample, its results nonetheless provide further empirical grounding and understanding of the concept of effective use, as well as further applicability and actionability to this concept and to the nomological network of its dimensions, contextual drivers and benefits in the case of PMIS and in the context of SMEs. Future research should however add technological, environmental and organizational context-related antecedents to this network, including first and foremost the IT infrastructural capabilities of the organization. Consequences other than performance should also be added, the priority being given to the consequences of the effective use of PMIS for the development of the dynamic capabilities that enable SMEs to remain competitive in a global, knowledge-based economy.

\section{References}

[1] Grover, V., and K. Lyytinen, "New state of play in information systems research: The push to the edges", $M I S$ Quarterly, 39(2), 2015, pp. 271-296.

[2] Boudreau, M.-C., and L. Seligman, "A learning-based model of quality of use: Insights from a case study of ERP implementation", DIGIT 2003 Proceedings, Association for Information Systems, paper 4, 2003, pp. 1-24.

[3] Burton-Jones, A., and C. Grange, "From use to effective use: A representation theory perspective", Information Systems Research, 24(3), 2013, pp. 632-658.

[4] Hsieh, J.J.P.A., and W. Wang, "Explaining employees' extended use of complex information systems", European Journal of Information Systems, 16(3), 2007, pp. 216-227.

[5] Busco, C., E. Giovannoni, and R.W. Scapens, "Managing the tensions in integrating global organisations: The role of performance management systems", Management Accounting Research, 19(2), 2008, pp. 103-125.

[6] Aspelund, A., and O. Moen, "Small international firms: Typology, performance and implications", Management International Review, 45(3), 2005, pp. 37-57.

[7] Marchand, M., and L. Raymond, "Researching performance measurement systems: An information systems perspective", International Journal of Operations \& Production Management, 28(7), 2008, pp. 663-686.

[8] De Toni, A., and S. Tonchia, "Performance measurement systems - models, characteristics and measures", International Journal of Operations \& Production Management, 21(1-2), 2001, pp. 46-70. 
[9] Franco-Santos, M., M. Kennerley, P. Micheli, V. Martinez, S. Mason, B. Marr, D. Gray, and A. Neely, "Towards a definition of a business performance measurement system", International Journal of Operations \& Production Management, 27(8), 2007, pp. 784-801.

[10] Evans, J.R. “An exploratory study of performance measurement systems and relationships with performance results", Journal of Operations Management, 22(3), 2004, pp. 219-232.

[11] Garengo, P., and U. Bititci, "Towards a contingency approach to performance measurement: an empirical study in Scottish SMEs", International Journal of Operations \& Production Management, 27(8), 2007, pp. 784-801.

[12] Straub, D., M. Limayem, and E. Karahanna, "Measuring system usage: implications for IS theory testing", Management Science, 41(8), 1995, pp. 1328-1342.

[13] Jain, V., and S. Kanungo, "Beyond perceptions and usage: Impact of nature of information systems use on information system-enabled productivity", International Journal of Human-Computer Interaction, 19(1), 2005, pp. 113-136.

[14] Burton-Jones, A., and D. Straub, "Reconceptualizing system usage: An approach and empirical test", Information Systems Research, 17(3), 2006, pp. 632-658.

[15] Chin W.W., and B.L. Marcolin "The future of diffusion research", The DATA BASE for Advances in Information Systems, 32(3), 2001, pp. 8-12.

[16] DeLone, W.H., and E.R. McLean, "The DeLone and McLean model of information systems success: A ten-year update", Journal of Management Information Systems, 19(4), 2003, pp. 9-30.

[17] Devaraj, S., and R. Kohli, "Performance impacts of information technology: Is actual usage the missing link?", Management Science, 49(3), 2003, pp. 273-289.

[18] Boynton, A.C., R.W. Zmud, and G.C. Jacobs, "The influence of IT management practice on IT use in large organizations", MIS Quarterly, 1994, pp. 299-318.

[19] Hou, C. "Examining the effect of user satisfaction on system usage and individual performance with business intelligent systems: An empirical study of Taiwan's electronics industry", International Journal of Information Management, 32(6), 2012, pp. 560-573.

[20] Barki, H., and S.L. Huff, "Change, attitude to change, and decision support system success", Information \& Management, 9(5), 1985, pp. 261-268.

[21] Agarwal, R., and E. Karahanna, "Time flies when you're having fun: Cognitive absorption and beliefs about information technology usage", MIS Quarterly, 24(4), 2000, pp. 665-694.
[22] Marcolin, B.L., D. Compeau, M.C. Munro, and S.L. Huff, "Assessing user competence: Conceptualization and measurement", Information Systems Research, 11(1), 2000, pp. 37-60.

[23] Cheung, C.M.K., and M. Limayem, "The role of habit in information systems continuance: examining the evolving relationship between intention and usage", Proceedings of the Twenty-Sixth International Conference on Information Systems, Las Vegas, 2005, pp. 471-482.

[24] Bourne, M., A. Pavlov, M. Franco-Santos, L. Lucianetti, and M. Mura, "Generating organizational performance: The contributing effects of performance measurement and human resource management practices", International Journal of Operations \& Production Management, 33(11/12), 2013, pp. 1599-1622.

[25] Bourne, M., J. Mills, M. Wilcox, A. Neely, and K. Platts, "Designing, implementing and updating performance measurement systems", International Journal of Operations \& Production Management, 20(7), 2000, pp. 754-771.

[26] Benbasat, I., and R.W. Zmud, "The identity crisis within the IS discipline: Defining and communicating the discipline's core properties", MIS Quarterly, 27(2), 2003, pp. 183-194.

[27] Wand, Y., and R. Weber, "On the deep structure of information systems", Information Systems Journal, 5(3), 1995, pp. 203-223.

[28] Weber, R. Still desperately seeking the IT artefact. MIS Quarterly, 27(2), 2003, pp. iii-xi.

[29] Hartson, H.R. "Cognitive, physical, sensory, and functional affordances in interaction design", Behavior and Information Technology, 22(5), 2003, pp. 315-338.

[30] Bititci, U. S., and S.S. Nudurupati, "Using performance measurement to drive continuous improvement", Manufacturing Engineering, 81(5), 2002, pp. 230-235.

[31] Garengo, P., S. Biazzo, and U.S. Bititci, "Performance measurement systems in SMEs: A review for a research agenda", International Journal of Management Reviews, 7(1), 2005, pp. 25-47.

[32] Sharif, A. M. "Benchmarking performance management systems", Benchmarking: An International Journal, 9(1), 2002, pp. 62-85.

[33] Smith, N.R., and J.B. Miner, "Type of entrepreneur, type of firm, and managerial motivation: Implications for organizational life cycle theory", Strategic Management Journal, 4(4), 1983, pp. 325-340.

[34] Raymond, L., M. Marchand, J. St-Pierre, L. Cadieux, and F. Labelle, "Dimensions of small business performance from the owner-manager's perspective: A re- 
conceptualisation and empirical validation", Entrepreneurship \& Regional Development, 25(5-6), 2013 pp. $468-499$.

[35] Lowry, P.B., J.E. Gaskin, and G.D. Moody, "Proposing the multimotive information systems continuance model (MISC) to better explain end-user system evaluations and continuance intentions", Journal of the Association for Information Systems, 16(7), 2015, pp. 515-579.

[36] Bititci, U.S., P. Garengo, V. Dörfler, and S. Nudurupati, "Performance measurement: Challenges for tomorrow", International Journal of Management Reviews, 14, 2012, pp. 305-327.

[37] Franco-Santos, M., L. Lucianetti, and M. Bourne, "Contemporary performance measurement systems: A review of their consequences and a framework for research", Management Accounting Research, 23, 2012, pp. 79-119.

[38] Kueng, P., A. Meier, and T. Wettstein, "Performance measurement systems must be engineered", Communications of the Association for Information Systems, 7(Article 3), 2001, pp. 1-27.

[39] Chenhall, R.H. "Integrative strategic performance measurement systems, strategic alignment of manufacturing, learning and strategic outcomes: an exploratory study", Accounting Organizations and Society, 30, 2005, pp. 395422.

[40] Gable, G.G., D. Sedera, and T. Chan, "Reconceptualizing information systems success: The IS-impact measurement model", Journal of the Association for Information Systems, 9(7), 2008, pp. 377-408.

[41] Seddon, P.B., V. Graeser, and L.P. Willcocks, "Measuring organizational IS effectiveness: An overview and update of senior management perspectives", DATA BASE for Advances in Information Systems, 33(2), 2002, pp. 11-28.

[42] Tallon, P.P., K.L. Kraemer, and V. Gurbaxani, "Executives' perceptions of the business value of information technology: A process-oriented approach", Journal of Management Information Systems, 16 (4), 2000, pp. 145-173.

[43] Strong, D.M., and O. Volkoff, "Understanding organization-enterprise system fit: A path for theorizing the information technology artifact", MIS Quarterly, 34(4), 2010, pp. 731-756.

[44] Miles, M.B., and A.M. Huberman, Qualitative data analysis - An expanded sourcebook, $2^{\text {nd }}$ edition, Sage, Thousand Oaks, California, 1994.

[45] Robson, C., Real World Research, $2^{\text {nd }}$ edition, Blackwell Publishers, Oxford, 2002.

[46] Yin, R. K. (2003). Case study research: Design and methods, $3^{\text {rd }}$ edition, Sage, Thousand Oaks, California, 2003.
[47] Boudreau, M.-C., D. Gefen, and D.W. Straub, "Validation in information systems research: A state-of-theart assessment", MIS Quarterly, 25(1), 2001, pp. 1-16.

[48] Lee, A.S and R.L. Baskerville, "Generalizing generalizability in information systems research", Information Systems Research, 14(3), 2003, pp. 221-243.

[49] Orlikowski, W.J., and C.S. Iacono, "Research commentary: Desperately seeking the 'IT' in IT research - A call to theorizing the IT artefact", Information Systems Research, 12(2), 2001, pp. 121-134.

[50] Spanos, Y. E., and S. Lioukas, "An examination into the causal logic of rent generation: Contrasting Porter's competitive strategy framework and the resource-based perspective", Strategic Management Journal, 22, 2001, pp. 907-934.

[51] Weerahandi, S., Exact Statistical Methods for Data Analysis, Springer-Verlag, New York, 1995.

[52] Runkel, P. J., Casting nets and testing specimens: Two grand methods of psychology, Praeger, New York, 1990.

[53] Hoyle, R.H., Statistical Strategies for Small Sample Research, Sage, Thousand Oaks, California, 1999.

[54] Sharma, S., Applied Multivariate Techniques, John Wiley \& Sons, New York, 1996.

[55] Leonardi, P.M., "Activating the informational capabilities of information technology for organizatioal change”, Organization Science, 18(5), 2007, pp. 813-831.

[56] Pavlou, P.A., and O.A. El Sawy, "Understanding the elusive black box of dynamic capabilities", Decision Sciences, 42(1), 2011, pp. 239-273.

[57] Fink, L., and S. Neumann, "Gaining agility through IT personnel capabilities: The mediating role of IT infrastructure capabilities", Journal of the Association for Information Systems, 8(8), 2007, pp. 440-462.

Appendix A: Measurement items of the effective use of PMIS

\begin{tabular}{|c|c|c|}
\hline $\begin{array}{l}\text { Transparent interaction } \\
\text { with the PMIS }\end{array}$ & $\begin{array}{l}\text { Representational } \\
\text { fidelity of the PMIS }\end{array}$ & $\begin{array}{c}\text { Informed action enabled } \\
\text { by the PMIS }\end{array}$ \\
\hline $\begin{array}{l}\text { The PMIS is: } \\
\text { - simple to use } \\
\text { - insures a secure and } \\
\text { confidential access } \\
\text { - filters the content by user } \\
\text { profile (personalized access) } \\
\text { - is interactive (Internet/Web } \\
\text { technology) } \\
\text { - is accessible from outside the } \\
\text { organization }\end{array}$ & $\begin{array}{l}\text { The PMIS produces } \\
\text { information that is: } \\
\text { - up to date } \\
\text { - relevant } \\
\text { - complete } \\
\text { - easy to use } \\
\text { - easy to interpret }\end{array}$ & $\begin{array}{l}\text { - allows me to verify } \\
\text { hypotheses } \\
\text { - allows me to better } \\
\text { understand my firm's } \\
\text { performance } \\
\text { - fosters the emergence of } \\
\text { new ideas on my part } \\
\text { - fosters my interest in } \\
\text { measuring and evaluating } \\
\text { my firm's performance } \\
\text { - fosters my interest in } \\
\text { applying appropriate } \\
\text { management practices }\end{array}$ \\
\hline
\end{tabular}

